\title{
Physico-chemical trends in the sediments of Agbede Wetlands, Nigeria
}

\section{Fizikalnokemične razmere $\mathrm{v}$ sedimentih agbedskih mokrišč v Nigeriji}

\author{
Abdul-Rahman Dirisu*, John Ovie Olomukoro, Ifeanyi Maxwell Ezenwa \\ Department of Animal and Environmental Biology, Faculty of Life Sciences, University of Benin, Benin city, P.M.B 1154, Nigeria \\ *dedonrahman10@yahoo.com, dirisu.abdul-rahman@lifesci.uniben.edu
}

\begin{abstract}
This study assessed the physico-chemical status of sediments in the Agbede Wetlands with the aim to create a reference archive for the Edo North catchment and to further identify the characteristics mostly influenced by the natural and anthropogenic activities going on at the watershed. Nutrients, zinc, nickel and lead were identified to be mostly of anthropogenic origin, while alkali metals and alkaline earth metals were from both anthropogenic and natural sources. The clustering of stations 1 and 4 indicates that the sediment quality in the lentic systems was not completely excluded from the lotic system, suggesting that principal component analysis (PCA) and cluster analysis (CA) techniques are invaluable tools for identifying factors influencing the sediment quality. The mean values of the particle size distribution were in the following order across the ecosystems: sand (61.86-80.53\%) > silt (9.75-30.34\%) $>$ clay $(7.83-13.89 \%)$. The contamination of the water bodies was primarily derived from agricultural run-offs and through geochemical weathering of the top soils. Therefore, our analysis indicates that the concentrations of cations, anions and nutrients in the sediments of the lotic and lentic ecosystems in Agbede Wetlands are not at an alarming level.
\end{abstract}

Key words: sediment, physico-chemical characteristics, pond, stream, principal component analysis, watershed

\section{Povzetek}

Raziskava obravnava fizikalnokemično stanje sedimentov $\mathrm{v}$ agbedskih mokriščih $\mathrm{z}$ namenom izdelati primerjalni arhiv severnega dela porečja Eda in natančneje opredeliti njegove značilnosti, na katere vplivajo naravni in antropogeni procesi v porečju. Ugotovili so, da so hranila, cink, nikelj in svinec pretežno antropogenega porekla, alkalne in zemeljskoalkalne kovine pa iz naravnih in antropogenih virov. Lega postaj 1 in $4 \mathrm{v}$ razvrščevalnem diagramu nakazuje, da kakovost sedimenta $\mathrm{v}$ lentičnih sistemih ni povsem izključena iz lotičnega sistema, iz česar sledi, da so metode PCA in CA (metoda glavnih komponent in metoda razvrščanja v skupine) zelo uporabne za prepoznavanje faktorjev, ki odločajo o kakovosti sedimenta. Srednje vrednosti porazdelitve zrnavosti v ekosistemih so naslednje: pesek (61.86$80.53 \%)$, > melj (9.75-30.34\%), > glina (7.83-13.89\%) Viri onesnaženja vodnih teles so predvsem v izpiranju obdelovalne zemlje in geokemičnem preperevanju vrhnjih tal. Iz opravljene raziskave sledi, da ugotovljene koncentracije kationov, anionov in hranil v sedimentih lotičnih in lentičnih ekosistemov v agbedskih mokriščih niso kritične.

Ključne besede: sediment, fizikalnokemične značilnosti, ribnik, vodni tok, analiza glavnih komponent, porečje 


\section{Introduction}

Sediments embody the critical elements of an aquatic ecosystem; they are collections of fine-, medium- and coarse-grained minerals and organic particles that are found at the bottom of lakes, ponds, rivers, streams, bays, estuaries and oceans [1, 2]. Fagbote and Olanipekun [3] have reported that the composition of sediments consequently provides the best natural archives of recent environmental changes. Sediments in an aquatic ecosystem play an important role in influencing the pollution state, as they can act as both carriers and sources of contaminants in an aquatic ecosystem. Ogbeibu et al. [2] have investigated the impact of anthropogenic activities, such as boating, dredging, transportation services, agriculture, fishing and oil exploitation, on the physico-chemical environment of the Benin River.

Sedimentsarerecognisedasimportantsinks, and some researchers in Nigeria have identified industrial and agricultural run-offs and geochemical processes such as weathering to be some of the possible source(s) of heavy metal contamination or pollution of the aquatic environment, which eventually sink to settle at the bed [4, 5, 2]. Kolo et al. [6] have studied the nutrient levels of the sediment in Lake Chad Basin in Borno State, Nigeria. The investigation has revealed high levels of sulphate $\left(26.20 \pm 5.65 \mu \mathrm{g} \cdot \mathrm{g}^{-1}\right)$, phosphate $\left(1325 \pm 8.00 \mu \mathrm{g} \cdot \mathrm{g}^{-1}\right)$ and nitrate $\left(3151 \pm 44.75 \mu \mathrm{g} \cdot \mathrm{g}^{-1}\right)$. The high values obtained during the dry season of the study were attributed to agricultural and fishing activities.

Sediments of lotic and lentic ecosystems not only act as important habitats to organisms but also serve as sinks to pollutants and as a nutrient source for aquatic organisms [7-9].

Generally, in Nigeria, works on sediments regarding physico-chemical characterisation are relatively few. It is also noteworthy that there is no research work available for the sediments of Agbede Wetlands till date. The purpose of this work was to assess the sediment quality in the Agbede Wetlands ecosystems by analysing the chemical composition, total organic carbon (TOC) content and particle size distribution. Furthermore, multivariate analysis was used to identify which parameter is mostly influenced by natural or anthropogenic activities taking place at the watershed.

\section{Materials and methods}

\section{Description of the study area}

The study area is part of the Agbede Wetlands (Figure 1) located in the northern part of Edo State within a rainforest ecosystem and fast becoming a derived savannah; it lies within the coordinates $06^{\circ} 52^{\prime} 0.2^{\prime \prime} \mathrm{N} / 06^{\circ} 16^{\prime} 0.3^{\prime \prime} \mathrm{E}$ and $06^{\circ} 55^{\prime} 0.4^{\prime \prime} \mathrm{N} / 06^{\circ} 18^{\prime} 0.7^{\prime \prime} \mathrm{E}$. Detailed descriptions of this locality have been previously published [10-12]. A descriptive summary of the sampling stations, type of water body, coordinates and sediment types is presented in Table 1.

A total of seven sampling stations were designated for this study, including one river (with three stations) and three ponds (with four stations). All the stations were carefully chosen based on accessibility, particularly during inundation periods. Station 1 was at a stretch of

Table 1: Summary of the sampling stations and sediment types in Agbede Wetlands

\begin{tabular}{|c|c|c|c|c|c|c|}
\hline \multirow{2}{*}{$\begin{array}{l}\text { Station } \\
\text { ID }\end{array}$} & \multirow{2}{*}{$\begin{array}{l}\text { Station/water } \\
\text { body type }\end{array}$} & \multirow[t]{2}{*}{ Macrophytes } & \multicolumn{2}{|c|}{ Coordinates } & \multirow[t]{2}{*}{ Altitude } & \multirow[t]{2}{*}{ Sediment type } \\
\hline & & & Latitude & Longitude & & \\
\hline 1 & Omodo Stream & Not present & $06^{\circ} 51^{1} 53^{\prime} .6^{\prime \prime} \mathrm{N}$ & $006^{\circ} 16^{\prime} 28^{\prime} .4^{\prime \prime} \mathrm{E}$ & $121 \mathrm{~m}$ & Sandy/pebbly \\
\hline 2 & Omodo Stream & Not present & $06^{\circ} 52^{\prime} 12^{\prime} .5^{\prime \prime} \mathrm{N}$ & $006^{\circ} 16^{1} 50^{\prime} .8^{\prime \prime} \mathrm{E}$ & $98 \mathrm{~m}$ & $\begin{array}{c}\text { Sandy/pebbly/ } \\
\text { muddy }\end{array}$ \\
\hline 3 & Omodo Stream & Present & $06^{\circ} 52^{1} 51^{\prime} .6^{\prime \prime} \mathrm{N}$ & $006^{\circ} 17^{1} 13^{\prime} .2^{\prime \prime} \mathrm{E}$ & $109 \mathrm{~m}$ & Silty/muddy \\
\hline 4 & Pond 1 & Present & $06^{\circ} 55^{1} 01^{\prime} .0 " \mathrm{~N}$ & $006^{\circ} 16^{1} 23^{\prime} .8^{\prime \prime} \mathrm{E}$ & $72 \mathrm{~m}$ & Sandy/muddy \\
\hline 5 & Pond 2 & Present & $06^{\circ} 56^{1} 14^{\prime} .6^{\prime \prime} \mathrm{N}$ & $006^{\circ} 16^{1} 15^{\prime} .4^{\prime \prime} \mathrm{E}$ & $79 \mathrm{~m}$ & Sandy/muddy \\
\hline 6 & Pond 3 & Present & $06^{\circ} 56^{1} 53^{\prime} .2^{\prime \prime} \mathrm{N}$ & $006^{\circ} 16^{1} 15^{\prime} \cdot 2^{\prime \prime} \mathrm{E}$ & $84 \mathrm{~m}$ & Sandy/muddy \\
\hline 7 & Pond 3 & Present & $06^{\circ} 56^{\prime} 57^{\prime} .4^{\prime \prime} \mathrm{N}$ & $006^{\circ} 16^{1} 15^{\prime} \cdot 2^{\prime \prime} \mathrm{E}$ & $82 \mathrm{~m}$ & Sandy/muddy \\
\hline
\end{tabular}




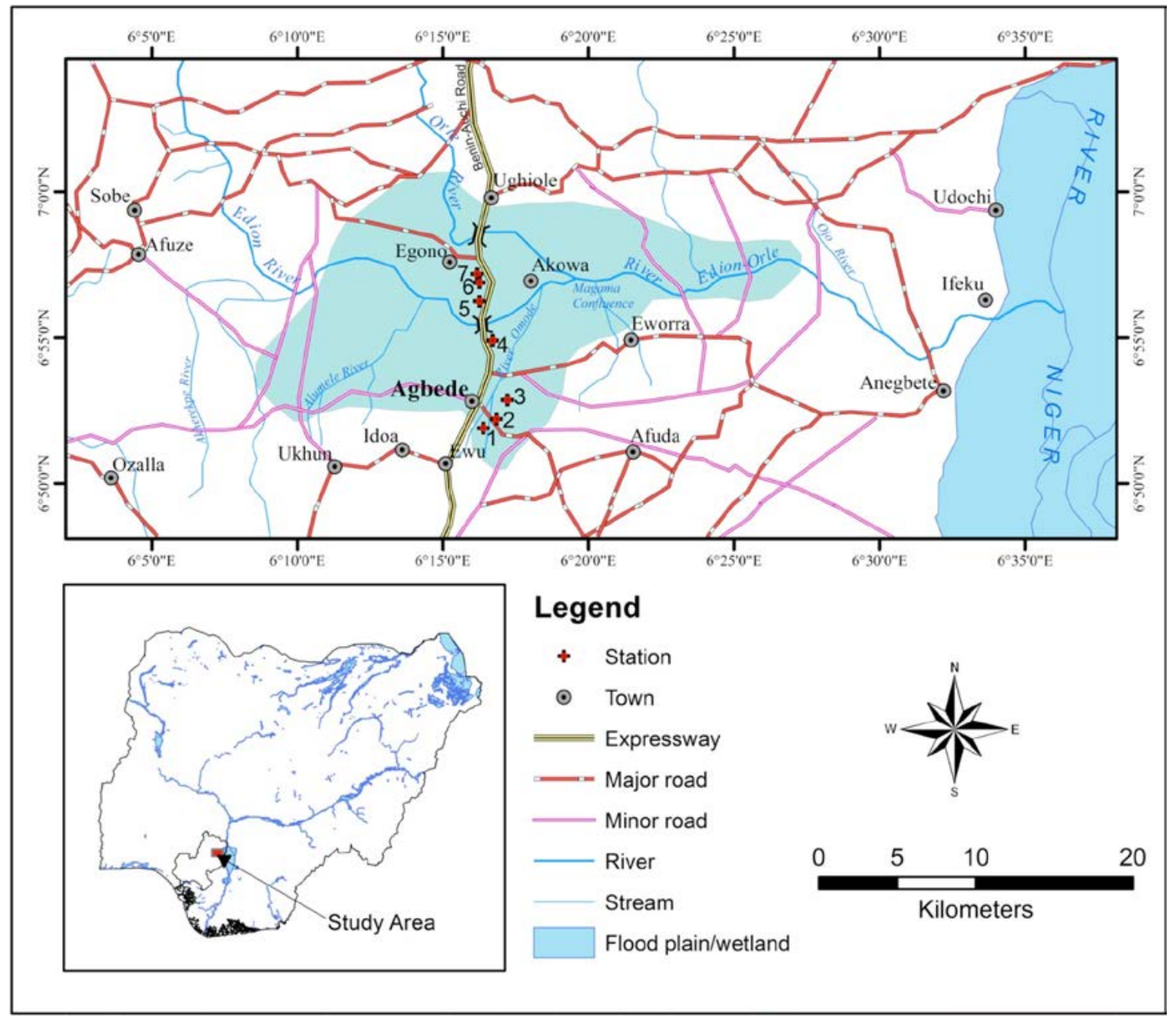

Figure 1: Map of the study area.

Omodo Stream located just by the confluence between Omodo and Egwavo streams, accessible through Ayuele Secondary School in Agbede town. The topography was characteristically a steep v-valley with lots of erosion streams when it rains and there was a dense canopy of Bambusa plants (Bambusa sp.). All forms of human activities, which include bathing, washing of clothes, fermentation of cassava and fishing, took place here. Station 2 was located at Odighie Village by the bridge linking Agbede and Amah/ Idegun towns, which was $>2.3 \mathrm{~km}$ from Station 1 . There was even more canopy cover from Bambusa sp. Washing of automobiles, bathing and washing of clothes were the major human activities here. Station 3 was about $2 \mathrm{~km}$ from Station 2 and was located by the bridge at Egho Village in the Rabho-Imes farm district.
It is the major source of water for every form of activity, such as drinking, washing and bathing, in the various farm camps. Cattle rearing can be listed as one of the activities at this site. Station 4 was located at the pond before Edion River when transiting to Auchi Town by the Ogwedion farm settlements and was located at a distance of about $5.3 \mathrm{~km}$. It is a major source of drinking water for the cattle-rearing nomads and a nestling ground for some bird species such as white cattle egret and weaver birds. It is fed by the Edion River during the peak wet seasons. There was sparse distribution of rooted macrophytes, such as Nymphaea lotus, Sacciolepis africana and Chromolaena odorata, at this site. Station 5 was a major but easily accessible pond at Ukatosoma farm district, which was around $2.4 \mathrm{~km}$ from Station 4 . It is mostly surround- 
ed by cassava and yam farms. It is also a major fishery ground, with biannual harvests. There were lots of macrophytes here (Nymphaea lotus and Acroceras zizanioides) and the banks were surrounded by deciduous trees. Station 6 was about $830 \mathrm{~m}$ away from Station 5 while travelling toward Auchi Town. It was a major source of drinking water to cattle herds within Ukatosoma farm district in Agbede. It was mostly surrounded by gmelina trees (Gmelina gmelina), along with macrophytes (Nymphaea lotus and Sacciolepis africana). Station 7 was the second station established on the same pond described for Station 6. It was located $<10 \mathrm{~m}$ away from the highway. There were yam farms on the west bank. Macrophytes were in abundance here, and the dominant species included Sacciolepis africana and Chromolena odorata.

\section{Sample collection and analysis}

Sediment samples were collected between 0900 and 1200 hours from the seven sampling stations on a monthly basis from December 2012 to May 2014. A light dredger operated by hand in shallow waters was used to collect the sediments $(n=126)$. The light dredger was forced into the sediment up to a depth of between 5 and $10 \mathrm{~cm}$, and the trapped substratum was introduced into a $15 \mathrm{~L}$ plastic bucket. An aggregate of five samples were pulled together to form one composite sample. The collected samples were sub-sampled, introduced into well-labeled black polythene bags and transported to the laboratory for analyses.

Hydrogen ion concentration $(\mathrm{pH})$ was determined in situ using a $\mathrm{pH} /$ conductivity meter (Hach pH meter, sensION 2 model). Electrical conductivity (EC) was equally measured in situ using the $\mathrm{pH} /$ conductivity meter. Nitrate, sulphate and chloride were analysed in the laboratory using the methods of Onyeonwu [13]. Phosphorus was extracted from the sediment sample using an extracting solution containing $0.03 \mathrm{M} \mathrm{NH}_{4} \mathrm{~F}$ and $0.025 \mathrm{M} \mathrm{HCl}$. The filtrate or supernatant for phosphorus determination was analysed using the single spectrophotometric method at a wavelength of $890 \mathrm{~nm}$ [14]. TOC content was determined in the laboratory using standard method [14]. Sodium, potassium, magnesium and calcium were analysed in the laboratory using the Thermo Jarrel Ash atom- ic absorption spectrophotometer (Series 2782, model 757). Oil and grease were determined in the sediment sample by the extraction/photometric method using the Hach spectrophotometer (UV/vis model DR 2000). Heavy metals in the sediment were determined in the laboratory using the total open digestion method [14]. Metals such as cadmium, zinc, iron, copper, lead, manganese, nickel and chromium were measured in milligrams per kilogram in the laboratory using the Thermo Jarrel Ash atomic absorption spectrophotometer. Particle size was determined in the laboratory using the modified pipette method [14].

\section{Data analysis}

Descriptive statistics that involve the measures of central tendency and dispersion were applied in order to elucidate the nature of the data generated. Principal component analysis (PCA) was applied to summarise the statistical correlation among the parameters and to further identify the parameter(s) that were most affected by natural or anthropogenic activities within this aquatic ecosystem. The varimax rotation of the generated PCA results was adopted. Varimax factor correlation coefficients of $>0.75,0.74-0.50$ and $0.49-0.30$ are considered as strong, moderate and weak factor loadings, respectively [15]. PCA is designed to transform the original variables into new, uncorrelated variables (axes), called the principal components, which are linear combinations of the original variables. The new axes lie along the directions of maximum variance. Cluster analysis (CA) was performed based on the mean values of the physical and chemical parameters characterised. CA uncovers the intrinsic structure or behaviour of a dataset without making a priori assumption about the data. It further classifies objects of the system into clusters based on their similarities. In the current analysis, Ward's method, which is a part of hierarchy CA, was applied for grouping and the dissimilarity was defined by the Euclidean distance. All mathematical and statistical computations were carried out using Microsoft Office Excel 2007, Statistical Package for the Social Sciences (SPSS 20.0) and Paleontological Statistics (PAST version 1.99) [16]. 


\section{Results}

\section{Spatial and temporal variability of physical and chemical characteristics in sediments}

The results for the 20 physico-chemical characteristics, including particle size distribution, which were determined in the sediments of the various water bodies under study, are discussed in the following sections. The summary showing the mean, minimum and maximum values are presented in Table 2. Spatial and temporal variations revealed that the concentrations were slightly higher during the dry seasons, particularly in the lentic environments.

$\mathrm{pH}$ values in the sediments exhibited spatial and temporal variations. The $\mathrm{pH}$ values were generally higher during the dry seasons of 2012, 2013 and 2014. pH values ranged between 4.80 (Stations 1, 6 and 7) and 7.00 (Station 2). The mean values were between 5.14 (Station 7) and 5.97 (Station 2). The minimum $\mathrm{pH}$ values were recorded in June 2013, July 2013, August 2013, November 2013, December 2013, January 2014 and March 2014.The maximum value was recorded in November 2013, as well as in January and March of 2014.

Oil and grease did not exhibit any definite seasonal pattern, except between December 2013 and April 2014, during which period a steady trend was observed. The spatial and temporal variations ranged between $0.0 \mathrm{mg} \cdot \mathrm{kg}^{-1}$ at Station 6 and $0.59 \mathrm{mg} \cdot \mathrm{kg}^{-1}$ at Station 1. Oil and grease were lowest in concentration in May 2013 and highest in August 2013, October 2013 and May 2014.

The mean TOC values ranged between $0.31 \%$ at Station 2 and $1.14 \%$ at Station 7. The minimum and maximum values ranged between $0.02 \%$ (Stations 1 and 3 ) and $2.50 \%$ (Station 7). The TOC value was highest in February and March 2014. However, TOC values were generally higher during the wet months throughout the study.

The minimum and maximum values of EC were between $34.32 \mu \mathrm{S} \cdot \mathrm{cm}^{-1}$ at Station 6 and $158.00 \mu \mathrm{S} \cdot \mathrm{cm}^{-1}$ at Station 7. The mean values ranged from $48.15 \mu \mathrm{S} \cdot \mathrm{cm}^{-1}$ at Station 2 to $99.98 \mu \mathrm{S} \cdot \mathrm{cm}^{-1}$ at Station 1. EC had maximum value in June 2013. The mean chloride concentrations ranged from $21.66 \mathrm{mg} \cdot \mathrm{kg}^{-1}$ at Station 6 to $33.14 \mathrm{mg} \cdot \mathrm{kg}^{-1}$ at Station 1. The maximum concentration of chloride in the sediments was $58.90 \mathrm{mg} \cdot \mathrm{kg}^{-1}$ at Station 7, which was recorded in August 2013, while a minimum concentration of $11.05 \mathrm{mg} \cdot \mathrm{kg}^{-1}$ was recorded in January 2013 at Station 6.

Among the nutrients, mean sulphate values were between $4.66 \mathrm{mg} \cdot \mathrm{kg}^{-1}$ (Station 7) and $8.05 \mathrm{mg} \cdot \mathrm{kg}^{-1}$ (Station 2). The minimum and maximum values ranged from $0.52 \mathrm{mg} \cdot \mathrm{kg}^{-1}$ at Station 6 to $21.70 \mathrm{mg} \cdot \mathrm{kg}^{-1}$ at Station 6. Spatial and temporal variations in sulphate levels fluctuated alongside seasonality, with higher values recorded in the wet season of 2013 (April-September). The spatial and temporal variations for nitrate ranged from a low of $0.02 \mathrm{mg} \cdot \mathrm{kg}^{-1}$ at Station 6 to a high of $29.30 \mathrm{mg} \cdot \mathrm{kg}^{-1}$ at Station 1 . The nitrate concentration in the sediment was lowest in November 2013 and highest in July 2013. Mean nitrate values ranged from $1.82 \mathrm{mg} \cdot \mathrm{kg}^{-1}$ (Station 5) to $6.63 \mathrm{mg} \cdot \mathrm{kg}^{-1}$ (Station 1). Mean phosphate values ranged from $2.80 \mathrm{mg} \cdot \mathrm{kg}^{-1}$ at Station 3 to $9.65 \mathrm{mg} \cdot \mathrm{kg}^{-1}$ at Station 6 . The spatial and temporal variations were between a low of $0.02 \mathrm{mg} \cdot \mathrm{kg}^{-1}$ at Station 1 and a high of $35.18 \mathrm{mg} \cdot \mathrm{kg}^{-1}$ at Station 6. Phosphate was highest in December 2012 and in January, February and March 2013 at Stations 1 and 7, respectively. Phosphorous content was not detectable between April and December of 2013. Spatial and temporal variations in the concentrations of alkali metals - sodium and potassium - showed almost the same trends. The minimum and maximum concentrations of sodium were between $3.62 \mathrm{mg} \cdot \mathrm{kg}^{-1}$ at Station 4 and $29.03 \mathrm{mg} \cdot \mathrm{kg}^{-1}$ at Station 7 , respectively. The minimum and maximum values of potassium were between $3.11 \mathrm{mg} \cdot \mathrm{kg}^{-1}$ at Station 5 and $32.50 \mathrm{mg} \cdot \mathrm{kg}^{-1}$ at Station 7 , respectively. Among the alkaline earth metals, mean calcium concentrations in the sediments ranged from $60.50 \mathrm{~g} \cdot \mathrm{kg}^{-1}$ at Station 2 to $120.72 \mathrm{mg} \cdot \mathrm{kg}^{-1}$ at Station 4. Calcium concentration was the lowest at Station 4 (12.32 $\left.\mathrm{mg} \cdot \mathrm{kg}^{-1}\right)$ in May 2013 and highest at Station 4 (230.00 $\left.\mathrm{mg} \cdot \mathrm{kg}^{-1}\right)$ in November 2013 and March 2014, respectively. Mean magnesium concentrations ranged between $46.53 \mathrm{mg} \cdot \mathrm{kg}^{-1}$ at Station 2 and $98.12 \mathrm{mg} \cdot \mathrm{kg}^{-1}$ at Station 4. Magnesium concentration was the lowest at Station 5 (21.73 $\left.\mathrm{mg} \cdot \mathrm{kg}^{-1}\right)$ in April and October 2013 and the highest at Station 4 (183.21 $\left.\mathrm{mg} \cdot \mathrm{kg}^{-1}\right)$ in November 2013. 


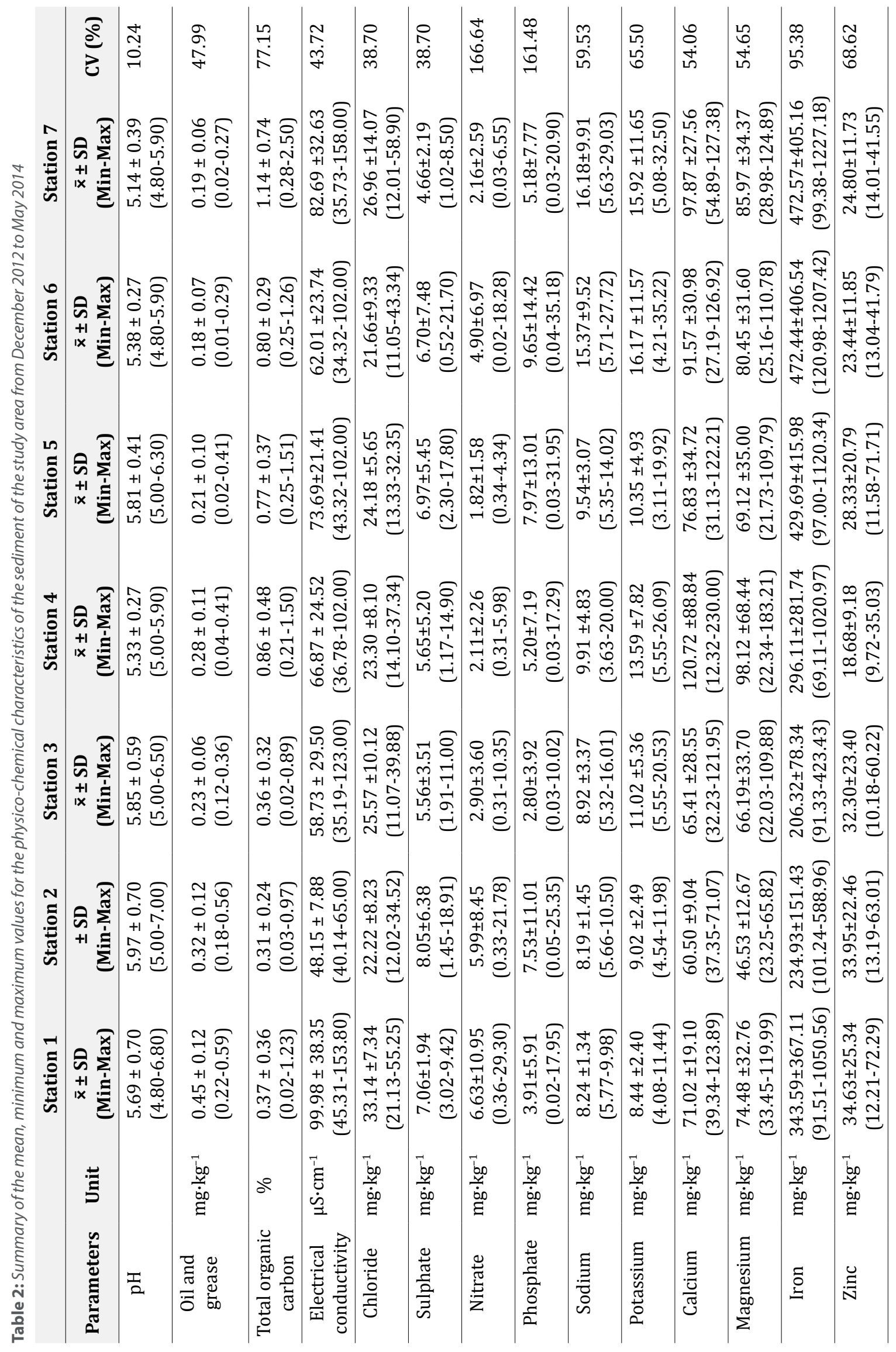




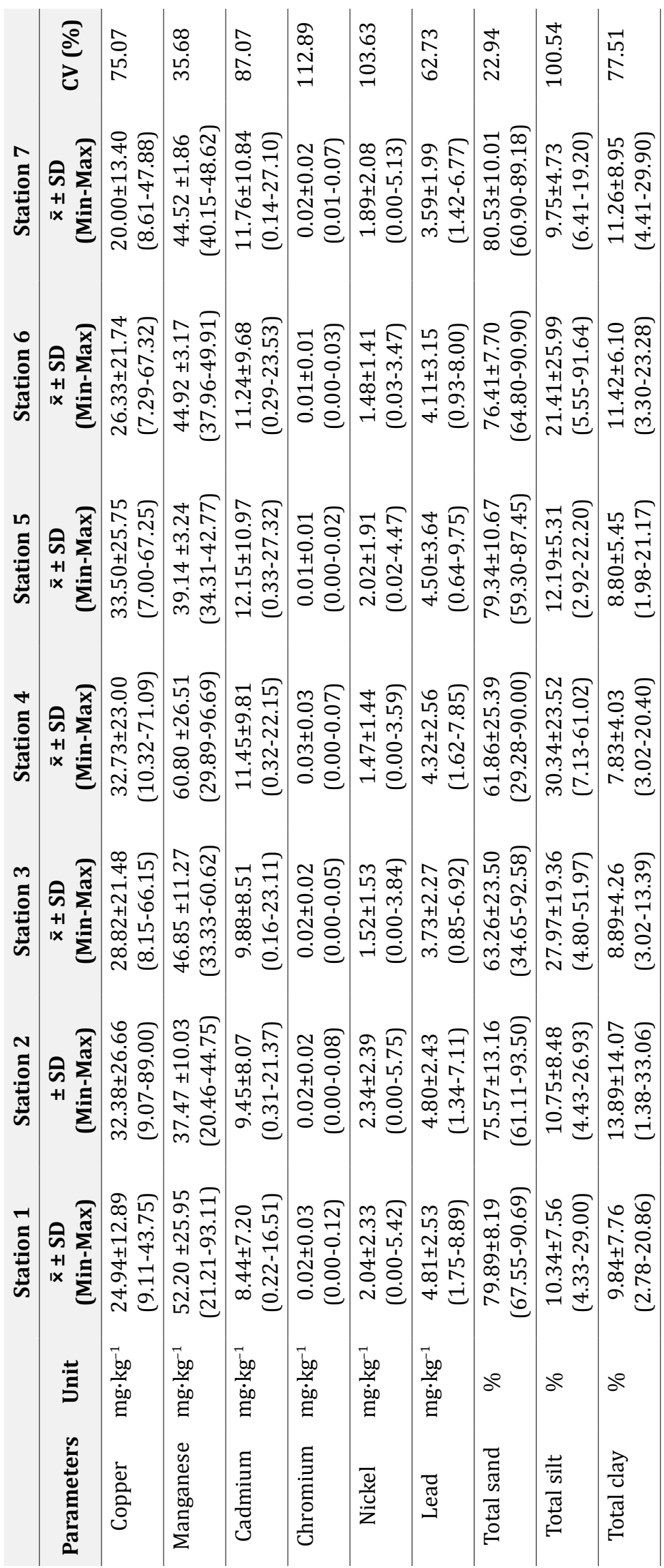


Heavy metal analyses revealed low-to-moderate concentrations, with iron values ranging from $69.11 \mathrm{mg} \cdot \mathrm{kg}^{-1}$ at Station 4 to $1227.18 \mathrm{mg} \cdot \mathrm{kg}^{-1}$ at Station 7. The mean values of iron were from $206.32 \mathrm{mg} \cdot \mathrm{kg}^{-1}$ at Station 3 to $472.57 \mathrm{mg} \cdot \mathrm{kg}^{-1}$ at Station 7 . The minimum value of $\mathrm{Fe}$ was recorded in January 2014, while the maximum was recorded in May 2014. Zinc recorded a low concentration of $9.72 \mathrm{mg} \cdot \mathrm{kg}^{-1}$ at Station 4 and a high concentration of $72.29 \mathrm{mg} \cdot \mathrm{kg}^{-1}$ at Station 1 . The mean concentrations were between $18.68 \mathrm{mg} \cdot \mathrm{kg}^{-1}$ at Station 4 and $34.63 \mathrm{mg} \cdot \mathrm{kg}^{-1}$ at Station 1. The mean copper concentrations in the sediments ranged between $20.00 \mathrm{mg} \cdot \mathrm{kg}^{-1}$ at Station 7 and $33.50 \mathrm{mg} \cdot \mathrm{kg}^{-1}$ at Station 4 . The minimum and maximum values were between $7.00 \mathrm{mg} \cdot \mathrm{kg}^{-1}$ at Station 5 and $89.00 \mathrm{mg} \cdot \mathrm{kg}^{-1}$ at Station 2 . The minimum and maximum concentrations of copper were recorded in November 2013 and December 2012, respectively. Manganese concentrations showed fluctuations across the stations. Mean manganese concentration ranged between $37.45 \mathrm{mg} \cdot \mathrm{kg}^{-1}$ at Station 2 and $60.80 \mathrm{mg} \cdot \mathrm{kg}^{-1}$ at Station 4 . The spatial and temporal values ranged from $20.46 \mathrm{mg} \cdot \mathrm{kg}^{-1}$ at Station 2 to $96.69 \mathrm{mg} \cdot \mathrm{kg}^{-1}$ at Station 4 . These values were recorded variously in July 2013 and January 2014. Conversely, mean cadmium concentrations showed an increase across the stations, from Station 1 to Station 7. Generally, the lentic systems (Stations 4-7) recorded higher values in terms of both spatial and temporal variations. The mean cadmium values ranged from $8.44 \mathrm{mg} \cdot \mathrm{kg}^{-1}$ at Station 1 to $12.15 \mathrm{mg} \cdot \mathrm{kg}^{-1}$ at Station 5. The minimum and maximum concentrations were $0.14 \mathrm{mg} \cdot \mathrm{kg}^{-1}$ at Station 7 and $27.32 \mathrm{mg} \cdot \mathrm{kg}^{-1}$ at Station 5. Cadmium concentration was lowest in April 2014 and highest in May 2014. Other metals included chromium, whose concentrations not only fluctuated irregularly but recorded values below the detection limit (BDL) in some stations. Chromium had values in the sediments ranging between $0.01 \mathrm{mg} \cdot \mathrm{kg}^{-1}$ (Stations 5 and 6) and $0.03 \mathrm{mg} \cdot \mathrm{kg}^{-1}$ (Station 4). Its spatial and temporal variations ranged between BDL at Stations 1-6 and $0.12 \mathrm{mg} \cdot \mathrm{kg}^{-1}$ at Station 1. Mean nickel concentrations ranged from $1.47 \mathrm{mg} \cdot \mathrm{kg}^{-1}$ at Station 4 to $2.34 \mathrm{mg} \cdot \mathrm{kg}^{-1}$ at Station 2 . The minimum and maximum concentrations of nickel were $0.00 \mathrm{mg} \cdot \mathrm{kg}^{-1}$ at Stations 1, 2, 3, 4 and 7 and $5.75 \mathrm{mg} \cdot \mathrm{kg}^{-1}$ at Station 2, respectively. Most of the values were found to be $<0.001 \mathrm{mg} \cdot \mathrm{kg}^{-1}$ across most of the stations and virtually throughout the sampling regime. The temporal and spatial variations for lead did not follow a specific pattern throughout this study, and the concentrations in the sediments were between $3.59 \mathrm{mg} \cdot \mathrm{kg}^{-1}$ at Station 7 and $4.81 \mathrm{mg} \cdot \mathrm{kg}^{-1}$ at Station 1 . Lead concentration was the lowest at Station $5\left(0.64 \mathrm{mg} \cdot \mathrm{kg}^{-1}\right)$ and the highest at Station $5\left(9.75 \mathrm{mg} \cdot \mathrm{kg}^{-1}\right)$.

Analysis of the sediments for particle size distribution revealed the three basic types, viz., sandy, silty and clayey, and in terms of mean percentage composition, the percentage composition of sandy sediment across the sampled stations (lotic sediment: Stations 1-3; and lentic sediment: Stations 4-7) was between $61.86 \%$ at Station 4 and $80.53 \%$ at Station 7. Mean silt composition was between $9.75 \%$ at Station 7 and $30.34 \%$ at Station 4 , while clay was between $7.83 \%$ at Station 4 and $13.89 \%$ at Station 2.

Among the parameters, $\mathrm{pH}$ recorded coefficient of variation (CV) $<20 \%$; for THC, EC, $\mathrm{Cl}, \mathrm{Mn}$ and total sand: $20 \%<\mathrm{CV}<50 \%$; for TOC, SO4, Na, K, $\mathrm{Ca}, \mathrm{Mg}, \mathrm{Fe}, \mathrm{Zn}, \mathrm{Cu}, \mathrm{Cd}, \mathrm{Pb}$ and total clay: $50 \%<$ $\mathrm{CV}<100 \%$, while NO3, PO4, Cr, Ni and total silt recorded $\mathrm{CV}>100 \%$.

\section{PCA of the parameters}

To identify the parameter(s) that were mostly influenced by natural or anthropogenic activities within the aquatic ecosystem, a PCA was performed. An exploratory factor analysis was also performed, to investigate the proportion of variation explained by each relative parameter, and a correlation matrix was produced (the primary data were used for the factor analysis), which was inspected for adequate determinant factor, sampling adequacy (Kaiser-Meyer-Olkin [KMO] test) and sphericity (Bartlett's test). Those factors that had eigenvalues $>1.0$ were extracted for further analyses using a PCA and rotated using varimax rotation. The KMO test indicated that sampling was adequate (i.e. KMO measure of sampling adequacy was $>0.5$ ) and the parameters' communalities were high (i.e. in excess of 0.5 ), suggesting that these parameters were reliable contributors to the analysis; there were sizeable correlations among all original variables and low correlations in the 


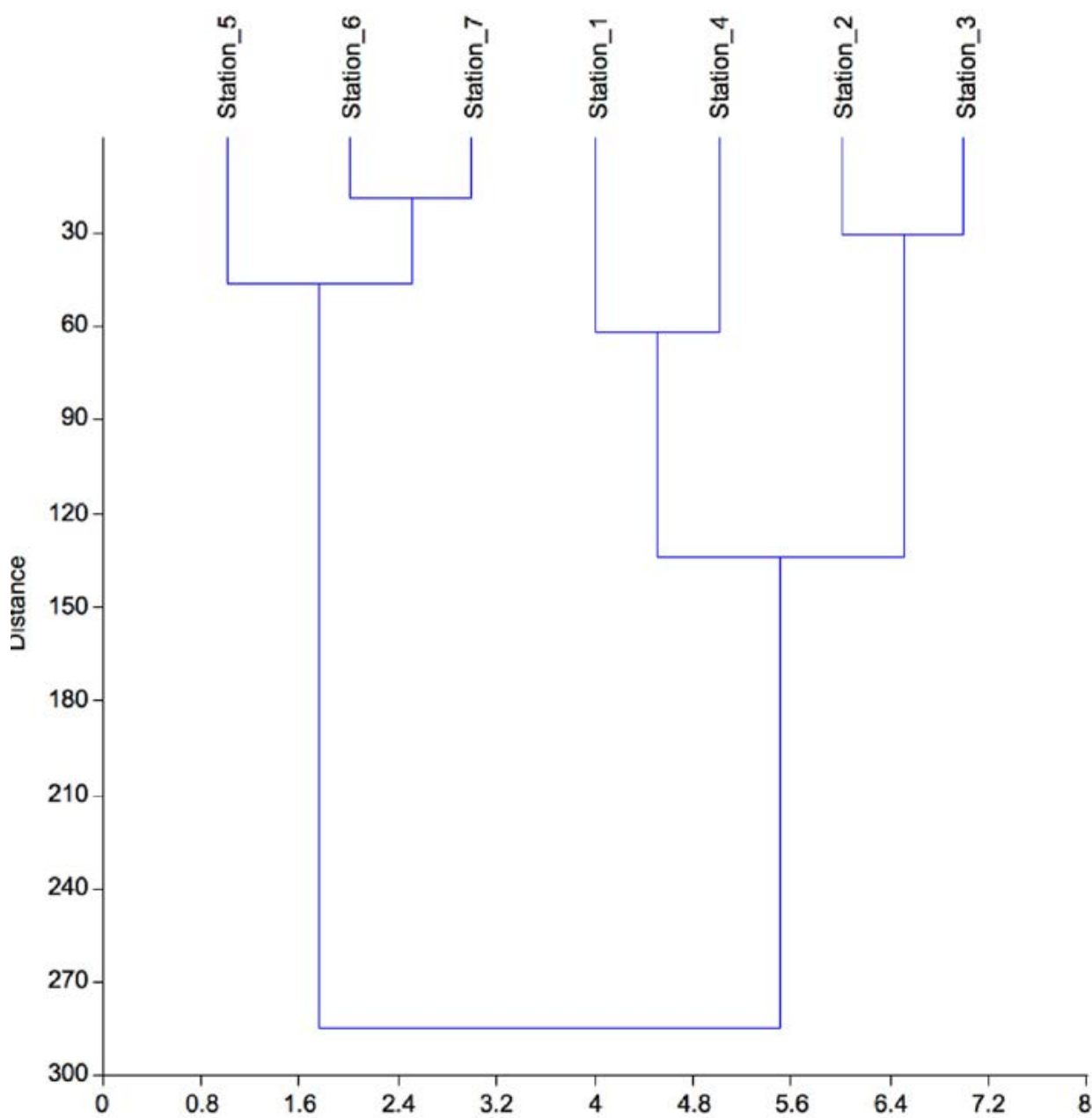

Figure 2: Dendogram for the cluster analysis based on the levels of all the parameters across the stations. The dissimilarity is defined by the Euclidean distance, and combination of clusters is based on Ward's method.

residual correlation matrix. The result of the PCA based on the correlation matrix of physical and chemical parameters is expressed in Table 3. The eigenvector classified the physical and chemical parameters into six components, which together accounted for $75.31 \%$ of the variance in the dataset. The contributions were as follows: components $1,2,3,4,5$ and 6 accounted for $20.107 \%, 15.061 \%, 11.951 \%$, $11.465 \%, 9.166 \%$ and $7.559 \%$, respectively. Adopting Liu et al. [15], the eigenvectors in the following components were considered to contribute either strongly or moderately to the overall variance:

- Component 1-strong factors: nickel, zinc, phosphate and nitrate; moderate factors: sulphate and lead;

- Component 2-strong factors: sodium and potassium; moderate factors: iron and TOC;
- Component 3-moderate factors: copper, manganese and cadmium;

- Component 4-moderate factors: calcium, magnesium, total sand and silt;

- Component 5-strong factor: EC; moderate factors: chloride, oil and grease;

- Component 6-strong factor: total clayey content; moderate factor: $\mathrm{pH}$.

\section{Euclidean similarity and distance indices}

Figure 2, showing the dendrogram for CA, indicates that the sampled stations varied and could be grouped into two major and four minor clusters. The four minor clusters include (i) Station 5, (ii) Stations 6 and 7, (iii) Stations 1 and 4 and (iv) Stations 2 and 3. These clusters of sampling stations indicated that each cluster had a sediment quality of its own, which was different from the other clusters. Considering 
Table 3: Eigenvectors and eigenvalues of the various sediment components

\begin{tabular}{lcccccc} 
& \multicolumn{7}{c}{ Component } \\
\cline { 2 - 7 } Parameters & $\mathbf{1}$ & $\mathbf{2}$ & $\mathbf{3}$ & $\mathbf{4}$ & $\mathbf{5}$ & $\mathbf{6}$ \\
\hline pH & -0.418 & -0.359 & -0.272 & 0.002 & 0.078 & -0.559 \\
\hline Oil and grease & 0.047 & -0.517 & -0.184 & 0.209 & 0.620 & 0.052 \\
\hline TOC & 0.084 & 0.748 & 0.054 & 0.234 & 0.035 & 0.394 \\
\hline EC & 0.132 & 0.288 & 0.055 & -0.052 & 0.840 & 0.039 \\
\hline Chloride & 0.347 & 0.110 & 0.185 & -0.171 & 0.636 & 0.018 \\
\hline Sulphate & 0.728 & 0.123 & 0.162 & -0.159 & 0.377 & 0.080 \\
\hline Nitrate & 0.792 & 0.066 & 0.065 & -0.022 & 0.101 & 0.185 \\
\hline Phosphate & 0.812 & 0.339 & 0.222 & -0.036 & 0.136 & 0.003 \\
\hline Sodium & 0.089 & 0.870 & -0.093 & -0.129 & 0.066 & -0.007 \\
\hline Potassium & 0.186 & 0.801 & -0.067 & 0.050 & 0.112 & -0.077 \\
\hline Calcium & -0.026 & 0.514 & -0.187 & 0.624 & 0.137 & 0.241 \\
\hline Magnesium & -0.159 & 0.443 & -0.156 & 0.720 & 0.190 & 0.053 \\
\hline Iron & -0.397 & 0.506 & -0.225 & 0.059 & 0.268 & 0.192 \\
\hline Zinc & 0.789 & -0.059 & 0.065 & -0.249 & 0.080 & 0.313 \\
\hline Copper & 0.464 & -0.179 & 0.698 & -0.132 & -0.004 & 0.039 \\
\hline Manganese & 0.014 & 0.025 & 0.742 & 0.040 & 0.156 & 0.249 \\
\hline Cadmium & 0.476 & -0.109 & 0.748 & -0.224 & -0.071 & -0.008 \\
\hline Chromium & -0.198 & 0.032 & -0.495 & 0.586 & 0.101 & -0.209 \\
\hline Nickel & 0.802 & 0.018 & 0.399 & -0.165 & 0.096 & 0.167 \\
\hline Lead & 0.615 & -0.105 & 0.605 & -0.188 & 0.059 & -0.052 \\
\hline Total sand & 0.241 & 0.181 & 0.049 & -0.722 & 0.320 & 0.441 \\
\hline Total silt & -0.162 & -0.267 & 0.046 & 0.697 & -0.354 & 0.017 \\
\hline Total clay & -0.225 & -0.016 & -0.147 & 0.076 & -0.071 & -0.832 \\
\hline Eigenvalues & 4.625 & 3.464 & 2.749 & 2.637 & 2.108 & 1.739 \\
\hline Proportion (\%) & 20.107 & 15.061 & 11.951 & 11.465 & 9.166 & 7.559 \\
\hline & 20.107 & 35.169 & 47.120 & 58.585 & 67.751 & 75.310 \\
\hline
\end{tabular}

the pair of Stations 1 and 4, the sediment quality in the lentic system was not completely excluded from the lotic system. The distances across the stations, as indicated by the gross variations in the physical and chemical parameters, are shown in Table 4.

Note: Extraction method: principal component analysis; rotation method: varimax with Kaiser normalisation; values $>0.75$ indicate strong factor loading, 0.74-0.50 indicate moderate factor loading and $0.49-0.30$ indicate weak factor loading.

\section{Discussion}

\section{Spatial and temporal variability}

Sediments have been described as a ready sink of pollutants, where they are concentrated according to the levels of pollution. Thus, the physico-chemical characteristics, including levels of trace metals, of river waters determine the quality of the sediment $[17,2]$. The study area is typically located on an alluvial floodplain, which is characterised by inundation of the banks of the water bodies, particularly rivers and streams, as well as most of the adjourning farmlands. In this situation, not only does 
Table 4: Euclidean similarity and distance indices across the stations

\begin{tabular}{lccccccc} 
& Station & Station & Station & Station & Station & Station & Station \\
& $\mathbf{1}$ & $\mathbf{2}$ & $\mathbf{3}$ & $\mathbf{4}$ & $\mathbf{5}$ & $\mathbf{6}$ & $\mathbf{7}$ \\
\hline Station 1 & 0.00 & & & & & & \\
\hline Station 2 & 125.82 & 0.00 & & & & & \\
\hline Station 3 & 146.18 & 44.42 & 0.00 & & & & \\
\hline Station 4 & 88.09 & 109.15 & 113.05 & 0.00 & & & \\
\hline Station 5 & 91.92 & 199.65 & 225.72 & 146.74 & 0.00 & & \\
\hline Station 6 & 138.23 & 243.23 & 268.64 & 181.90 & 52.20 & 0.00 & \\
\hline Station 7 & 134.79 & 247.21 & 271.62 & 183.12 & 55.80 & 27.46 & 0.00 \\
\hline
\end{tabular}

geochemical weathering of the top soils take place but organic materials such as nutrients are also transported via run-offs into the nearest water body, where they may become resident over time. Spatial heterogeneity obtained in the levels of the various parameters characterised in this study was not unusual; Stuart et al. [18] asserted that it involves microniches with high concentrations of contaminants and high bacterial activity. Moreover, the CVs of the parameters analysed showed high values, and according to Han et al. [19], CV values of elements dominated by natural sources are relatively low, while CV values of elements influenced by non-natural sources (biological and anthropogenic) are relatively high [20]. In the current study, the CV values of all the parameters except $\mathrm{pH}$ were $>20 \%$. The relatively low value of $\mathrm{CV}$ obtained for $\mathrm{pH}$ can be attributed to the fact that it has a fixed range, thus the influence of any factor on it influences either its acidity or alkalinity. For the other parameters, factors such as the parameter's residence time, rate of input together with the concentration, interaction among the parameters and the prevailing physical environmental conditions can have influence on their concentrations at any given time.

The $\mathrm{pH}$ values in the sediments were higher during the dry season months; however, the $\mathrm{pH}$ values ranged between 4.80 (Stations 1, 6 and 7) and 7.00 (Station 2) in our study. The acidic nature of the sediment was not surprising as it was typical of most water bodies in the Niger Delta ecological zone due to anaerobic sediments [2]. Contrary to the report by Ogbeibu et al. [2], for Benin River, no form of homogeneity was observed in the grouping of the mean po- tential of hydrogen ions in relation to either the lotic or the lentic systems. The reduction in the $\mathrm{pH}$ during the wet season was attributed to the influx of acid hydrides via precipitation. The $\mathrm{pH}$ range found in this investigation falls within the limits of 4.0-7.00 [21], aiding the survival of fish species in the aquatic environment.

Oil and grease in the sediments of the selected water bodies in Agbede Wetlands were sourced primarily from automobile washing. The values did not remarkably follow any definite seasonal and spatial patterns. The human impact on these water bodies with oil and grease was mostly associated with Stations 1 and 2 (lotic system) and Station 5 (lentic system), where an accidental diesel spill occurred in January 2013 involving a delivery tanker. High levels of variation were obtained among the mean values of the concentrations and the values were ecologically quite insignificant.

TOC can have its origin from either organic matter from natural sources such as plant materials deposited on sediments or anthropogenic inputs to aquatic systems [8]. It provides a measure of how much organic matter occurs in sediments. The TOC concentrations were much lower when compared to the results in the work of Adeyemo et al. [8] in Ibadan city (values $>0.31-1.14 \%$ of the mean range in this study). These concentrations were lower than what has been reported for the Benin River sediment [2]. Hyland et al. [22] found that extreme concentrations of TOC can have adverse effects on benthic communities. TOC levels $<0.05 \%$ and $>3 \%$ were related to reduced benthic abundance and biomass. Values $<0.05 \%$ or $>3 \%$ may be indicative of unfavourable environment for benthos. The TOC values were 
higher during the wet seasons, which may be due to the influx of organic matters from runoffs and other decomposing matter within the water bodies.

EC had higher mean concentrations in the ponds than in the stream, except at Station 1 of the stream, which recorded the highest mean value - this probably resulted from the fact that the pond can serve as a sink for different ion species; moreover, the high level of EC recorded at Station 1 could be related to the intense human activities at the station and also the resultant ionic content of the Omodo and Egwavo Streams, which established a confluence near that point. The concentrations were found to be within what was recorded for Warri River [23] but much lower than what was reported for Benin River by Ogbeibu et al. [2] and in the Adoni flats in the Niger Delta by Ansa and Francis [24]. These differences can be attributed to the nature of activities carried out at the shed of these different aquatic environments and the proximity between the aquatic bodies and salt water within the ecological type.

Nutrient concentrations in the sediments were close to the values that have been documented for the major rivers in the Niger Delta draining other water bodies - the Warri River and the Benin River [23, 2]. The nutrient concentrations seem to be higher during the wet seasons. There was no clear-cut variation among the chemical characteristics (sulphate, nitrate and phosphate) regarding the spatial trends in both ecological types (lotic and lentic systems). Instead, there was fluctuation in the concentrations. The values obtained in this study were higher than those of Warri River [2] but within the range reported by Kolo et al. [6] for Lake Chad Basin in Borno State, Nigeria. Furthermore, no clear distinction was recorded in the concentrations of these nutrients across the stations; nitrate and phosphate maintained the highest values of CV. These in turn represent the non-point source input of these nutrients and the intense influence of artificial and biological activities on the nutrients. On average, phosphate was highly retained in the sediment of these wetlands than nitrate.

Sodium and potassium concentrations showed marked variation in the lentic environments; this could be related to the water retention time in the lentic environment and the characteristically sink nature of the lentic environment. The water retention time, which was typically higher in the lentic than the lotic environment, enhances the chances of alkali metals bonding with other elements or compounds for which they have affinity. The CVs of sodium and potassium were relatively similar; this could be attributed to the fact that both elements share similar characteristics physically and chemically. In addition, these two elements might have been sourced via the same point in these wetlands, such as through weathering processes. The alkaline earth metals (calcium and magnesium) exhibited some homogeneity in concentrations, resembling the trends in the alkali metals. The alkaline earth metals recorded relatively equal $\mathrm{CV}$ values. The mean concentrations of calcium and magnesium cations were apparently higher in the lentic ecosystems - the same factors as applicable to the alkali metals might be responsible. However, Station 1 (lotic environment) had significantly higher values for both cations (Table 2). This may be due to the presence of pebbles at the station, which give off the contents in solution. Meanwhile, the concentrations were higher than what was documented [2] for Benin River within the Niger Delta of Nigeria. The intra-specific variations for both alkali metals and alkaline earth metals maintained more static condition in the lentic system than in the lotic system.

The high concentrations of $\mathrm{Fe}$ in the sediments could be due to the geological mineral compositions of Edo North, aggravated by the action of agents of nature such as precipitation and weathering as influenced by hydrogeochemistry. In addition, iron has been reported to occur at high concentrations in Nigerian soil/sediment [25]. The range of mean concentrations in this study (206.32-472.57 $\left.\mathrm{mg} \cdot \mathrm{kg}^{-1}\right)$ was higher than that in some existing works [4] for Ekpan Creek in Warri [2] and for Benin River, both in the Niger Delta of Nigeria.

Zinc concentrations in the sediments appeared to be higher in the stream (lotic system). The ranges recorded for zinc were in multiples of what have been reported in some studies within Nigerian aquatic ecosystems [4, 26]. Manganese concentrations were exceptionally very high when compared with the work of Ogbei- 
bu et al. [2]. These exceptionally high values, which varied spatially, may have been sourced from the geochemical impact of the underlying minerals (rocks) of Agbede and the entire Edo North geology. Copper showed trends in concentrations similar to that of manganese. The spatial and temporal variations observed in this study may have been influenced by the amount of precipitation. Copper concentrations may have also been contributed by the use of pesticide chemicals and the lead dry cells (batteries) by the herdsmen living there. These findings are contrary to the results by Olomukoro and Azubuike [4] and Ogbeibu et al. [2]. There was a gradual increase in the temporal and spatial concentrations of cadmium in the sediments across the seasons. Generally, the lentic stations recorded higher values, which could be explained by the lentic nature of the water bodies. Chromium concentrations were mostly not detectable in the sediment samples between Stations 1 and 6 within some months during the sampling regime; these variations accounted for the high $\mathrm{CV}$ recorded in relation to it. Chromium cations are known to reach aquatic environments primarily from the discharge of industrial waste materials and the use of products containing the metal [27, 28, $2]$. The chromium values were low when compared to those reported by Ogbeibu et al. [2] for Benin River. These concentrations could be derived from natural sources other than anthropogenic sources such as from industrial wastes and through corrosion of its scrap metals. Lead has been reported to be toxic to humans, and its major sources include the use of lead as petrol additive, run-off from cities/towns, discharge of improperly treated waste effluents, sewage sludge and the use of pesticides containing lead compounds $[27,2]$. The mean concentrations of $\mathrm{Pb}$ across the stations were lower than the mean concentrations obtained for Ekpan Creek in Warri, Nigeria [4], but were higher than what was obtained for the Benin River stretch [2]. The contamination of surface waters of Agbede town by $\mathrm{Pb}$ is believed to originate from the atmospheric $\mathrm{Pb}$ as a product of combustion of leaded fuel brought down by rainfall. The lentic systems are located by the Auchi-Abuja highway and thereby are exposed to inputs of large deposits of incomplete combustion of leaded fuel. The lotic stations received $\mathrm{Pb}$ from the washing of automobiles and from the run-offs draining agricultural lands.

Particle size distribution is vital to aquatic ecology in that it determines the distribution of macrobenthos and the type(s) of ions it retains as a sink. The sediments of Agbede Wetlands were chiefly dominated by a high proportion of sandy particles (mean composition between $61.86 \%$ and $80.53 \%$ ). The dominance of sandy sediments across many water bodies in Agbede Wetlands and others within Edo North is a true reflection of the geology, which is very friable with huge amounts of sandy topsoils. The dominance of sandy sediments in an aquatic environment was reported [24] for the Adoni flats in the Niger Delta; sandy sediments seem not to support a diverse community of infauna.

\section{Potential parameters influencing the physico-chemical status of Agbede Wetlands}

PCA was applied to the physico-chemical parameter data in order to determine the basic statistical relationships and further as a means of multivariate analysis to group natural and key anthropogenic input types. The PCA result for the Agbede Wetlands dataset involved six principal components (PCs) with eigenvalues $>1$, explaining approximately $75.31 \%$ of the information contained in the total variables (Table 3).

The first principal component (PC 1) accounted for $20.11 \%$ of the total variance and was primarily loaded with soil nutrient parameters and trace elements - phosphate, nitrate, sulphate, zinc, nickel and lead. These loadings generally represent agricultural activities (use of fertilisers, pesticides, herbicides and so on), terrigenous sources and activities involving the use of detergents and processing of foodstuffs such as starch fermentation. PC 2, which explained $15.06 \%$ of the total variance, had high loadings for the alkali metals - sodium and potassium, as well as for TOC; dominant loadings on these parameters generally represent detrital components. The grouping of TOC with alkaline elements indicates that elements were released from decaying organic matters and the possible incidence of anthropogenic inputs. The inclusion of the anthropogenic parameter TOC further suggests that alkali metals are probably 
not of marine deposit. The low loading accorded to the heavy metals in PC 2 contradicted the assertion by Singh et al. [29] that TOC controls the uptake of heavy metals by the sediment. PC 3 had high loadings for some trace elements - copper, manganese, cadmium and lead; this implies dominant terrigenous sources and also disposal of trace metal-laden matter. PC 4 had strong loading for alkaline earth metals and total silt; this component can be attributed to the action of weathering processes such as the breaking down of rocks, releasing alkaline earth metals and further influencing the silt content of the associated system. Weathering of rock influences the particle size composition of earth and, further, the release of some of its constituent elements. Further insight into PC 4 revealed that, with the exception of chromium, the other parameter loadings were very low; this implies that calcium and magnesium input into this ecosystem is probably of anthropogenic origin because of the low loading of the associated lithogenic parameters. PC 5 had oil and grease, EC and chloride among the parameters of importance; this component can be attributed to domestic activities revolving around washing of kitchen utensils, clothes and automobiles via the use of soaps and detergents, as well as disposal of waste food. Chloride, being a strong ionic entity, can influence the EC of the ecosystem. Adeyi and Majolagbe [30] related the chloride contamination of aquatic bodies to food waste. PC 6 showed negative loadings for $\mathrm{pH}$, sodium, potassium, cadmium, nickel and clay and a moderate loading for total sand. This component implies the action of earth-dislodging activity such as erosion. In general, the $\mathrm{pH}$ and the total clay and sand content, having low eigenvectors in most components, were among the least influenced and important parameters in these aquatic ecosystems. These three parameters also recorded low $\mathrm{CV}$.

\section{Euclidean similarity and distance indices}

CA was another multivariate analysis adopted in this study. CA has proved valuable in solving classification hitches where the objective is to sort variables into groups, such that the degree of association is strong between members of the same cluster and weak between members of different clusters [31]. In an aquatic ecosys- tem, the CA technique is a useful tool that offers reliable classification of matrix components and makes it possible to carry out spatial assessment in an optimal manner [32]. Sites in the same cluster often possess similar characteristics and natural background source types [33]. The result of CA clustered the sediment quality into four groups. The lowest and highest distances in pair-wise manner were obtained between Stations 3 and 7 and between Stations 6 and 7, respectively. The clustering of Stations 1 and 4 indicates that the sediment quality in the lentic system was not completely excluded from the lotic system; this further revealed that both are of the same origin. The CA results revealed that this multivariate approach was useful in offering reliable classifications of sediment in the study area and optimising the design of a future spatial sampling strategy. Thus, it can be said that for quick spatial assessments of the sediment quality, one site sampled in each cluster is sufficient to determine the sediment quality of the entire area.

\section{Conclusion}

Our analysis indicates that the concentrations of cations, anions and nutrients in the sediments of the lotic and lentic ecosystems in Agbede Wetlands are not at an alarming level. The contamination of the water bodies was primarily sourced from agricultural run-offs and through geochemical weathering, particularly of the topsoils, with reference to the sandstone-predominant earth. Siltation could be a more worrisome phenomenon in the near future owing to the high percentages of sand and silt being deposited in the systems during the wet seasons. The direct defecation by bovines into the water bodies while grazing could become a major source of nutrient load if not checked at current levels.

\section{Acknowledgements}

The first author thanks Messrs Linkon Osama and Festus Arijiode, who volunteered as field assistants during the study. He also gratefully acknowledges the financial support from the 
Nigerian Conservation Foundation (NCF) in the form of the Chief S.L Edu Research Grant for PhD study, which greatly spurred the success of this work. Samples were jointly analysed at the EarthQuest Laboratory, Warri. We thank the two anonymous reviewers and Dr. Elisha Enabulele who criticised the use of language.

\section{References}

[1] Adams, W.J., Kinerle, R.A., Barnette, J.W. (1992): Sediment quality and aquatic life assessment. Environmental Science and Technology, 26, pp.1865-1875.

[2] Ogbeibu, A.E., Omoigberale, M.O., Ezenwa, I.M., Eziza, J.O., Igwe, J.O. (2014): Using Pollution Load Index and Geoaccumulative Index for the Assessment of Heavy Metal Pollution and Sediment Quality of the Benin River, Nigeria. Natural Environment, 2, pp. 1-9.

[3] Fagbote, E.O., Olanipekun, E.O. (2010): Evaluation of the status of heavy metal pollution of sediment of Agbabu bitumen deposite area, Nigeria. European Journal of Scientific Research, 26, pp. 437-442.

[4] Olomukoro, J.O., Azubuike, C.N. (2009): Heavy metals and Macroinvertebrate Communities in Bottom Sediment of Ekpan Creek, Warri, Nigeria. Jordan Journal of Biological Sciences, 2, pp. 1-8.

[5] Enuekun, A.A., Ezemonye, L.T., Ainerua, M.O. (2014): Human health risk assessment of metal contain nation through consumption of Sesarma angolense and Macrobrachuim macrobranchium from Benin River, Nigeria. European International Journal of Science and Technology, 3, pp. 77-86.

[6] Kolo, B.G., Ogugbuaja, V.O., Dauda, M. (2010): Study on the level of Sulphates, Phosphates and Nitrates in Water and Aqueous Sediments of Lake Chad basin area of Borno State, Nigeria. Continental Journal of Water, Air and Soil Pollution, 1, pp. 13-18.

[7] Stronkhorst, J., Brits, J., Batty, J., Coquery, M., Mannio, J., O’Donnell, C., Steenwijk, J, Frintrop, P. (2004): Discussion document on sediment monitoring guideline for EU water framework directive. Version 2.EU water framework directive expert group on Analysis and Monitoring of Priority Substances. May 25 ${ }^{\text {th }}, 2004$.

[8] Adeyemo, O.K., Adedokun, O.A., Yusuf, R.K., Adeleye, E.A. (2008): Seasonal changes in physicochemical parameters and nutrient Load of River Sediments in Ibadan City, Nigeria. Global NEST Journal, 10, pp. 326-336.

[9] Marathe, R.B., Marathe, Y.V., Sawant, C.P. (2011): Sediment characteristics of Taptic Riverm India. Inter- national Journal of Chemical Technology Research, 3, pp. 1179-1183.

[10] Olomukoro, J.O., Dirisu, A.R. (2012): Macroinvertebrate Community of a post Lindane treated Stream flowing through derived Savannah in Southern Nigeria. Tropical Freshwater Biology, 21, pp. 67-82.

[11] Olomukoro, J.O., Osamuyiamen, I.M., Dirisu, A.R. (2013): Ecological Survey of Macrobenthic Invertebrates of selected ponds in Agbede flood plain, Southern Nigeria. Journal of Biology, Agriculture and Healthcare, 3, pp. 23-29.

[12] Dirisu, A.R., Olomukoro, J.O. (2015): Investigation of Water Quality of two Rivers in Agbede wetlands in Southern Nigeria. Global NEST Journal, 17, pp. 451462.

[13] Onyeonwu, R.O. (2000): Manual for Waste/Wastewater, Soil/Sediment, Plant and Fish analysis. Benin City: MacGill Environmental Research Laboratory Manual. 81pp.

[14] APHA (American Public Health Association) (2005): Standard methods for the examination of water and wastewater. 21st edition, Eaton, A.D., Clesceri, L.S., Rice, E.W., Greenberg, A.E., Franson, M.A.H. APHA, Washington D. C., U.S.A.

[15] Liu, C.W., Lin, K.H., Kuo, Y.M. (2003): Application of Factor Analysis in the Assessment of Groundwater Quality in a Blackfoot Disease Area in Taiwan. Science of the Total Environment, 313, pp. 77-89.

[16] Hammer, F., Harper, D.A.T., Ryan, P.D. (2001): PAST: Paleontological statistics software Package for education and data analysis. Palaeontologia Electronica, 4, pp. 1-4.

[17] Onyari, M.J., Muohi, A.W., Omondi, G., Mavuti, K.M (2003): Heavy metals in sediments from Makupa and Port -Reitz Creek Systems. Kenyan Coast Environment International, 28, pp. 639-647.

[18] Stuart, L.S., Graeme, E.B., Anthony, A.C., Jenny, L.S., Catherine, K.K., John, C.C., Ross, V.H., Sharyn, A.G., Anthony, C.R., William, A.M. (2005): Handbook for Sediment Quality Assessment. Centre for environmental contaminant research, CSIRO Energy technology, Bangor; NSW. 117 pp.

[19] Han, Y.M., Du, P.X., Cao, J.J., Posmentier, E.S. (2006): Multivariate analysis of heavy metal contamination in urban dusts of Xi'an, central China. Science of the Total Environment, 355, pp. 176-186.

[20] Han, Y.M., Du, P.X., Cao, J.J., Posmentier, E.S. (2006): Multivariate analysis of heavy metal contamination in urban dusts of Xi'an, central China. Science of the Total Environment, 355, pp. 176-186. 
[21] Guo, G., Wu, F., Xie, F., Zhang, R. (2012): Spatial distribution and pollution assessment of heavy metals in urban soils from southwest China. Journal of Environmental Science, 24, pp. 410-418.

[22] World Health Organization (WHO) (2006): Guidelines for Drinking-Water Quality. First addendum to $3^{\text {rd }}$ ed. 1, Recommendation. J. Hydrol Geneva, WHO (World Health Organization), pp. 595.

[23] Hyland, J., Karakassis, I., Magni, P., Petrov, A., Shine, J. (2000): Summary Report: Results of initial planning meeting of the United Nations Educational, Scientific and Cultural organization (UNESCO) Benthic Indicator Group, pp. 70.

[24] Olomukoro, J.O., Egborge, A.B.M. (2003/2004): Hydrobiological Studies on Warri River Nigeria. Part II: Seasonal Trends in the physic-chemical Limnology. Tropical Freshwater Biology 12/13, pp. 9-13.

[25] Ansa, E.J., Francis, A. (2007): Sediment characteristics of the Adoni Flats, Niger Delta, Nigeria. Journal of Applied Science and Environmental Management, 11, pp. 21-25.

[26] Adefemi, O.S., Asaolu, S.S., Olaofe, O. (2007): Assessment of the physico-chemical status of water samples from major dams in Ekiti State, Nigeria. Pakistan $\mathrm{Nu}$ trition, 6, pp. 657- 659.

[27] Oyekunle, J.A.O., Ogunfowokan, A.O., Akanni, M.S., Torto, N. (2011): Seasonal mean levels of heavy metals in water and associated sediments from Ajawere River in Oke-Osun farm settlement, Osogbo, Nigeria. Proceedings of the Environmental Management Conference, Federal University of Agriculture, Abeokuta, Nigeria.
[28] Radojevic, M., Bashkin, V.N. (1999): Practical environmental analysis. Royal Society of Chemistry: Cambridge, UK; 466 pp.

[29] Akan, J.C., Abdulrahman, F.I., Sodipo, O.A., Ochanya, A.E., Askira, Y.K. (2010): Heavy metals in sediments from River Ndaga, Maiduguri Metropolis, Borno State, Nigeria. Journal of Environmental Chemistry and Ecotoxicology, 2, pp. 131-140.

[30] [29] Singh, M., Mulle, G., Singh, I.B. (2002): Heavy metals in freshly deposited stream sediments of rivers associated with urbanisation of the Ganga plain, India. Water Air Soil Pollution, 141, pp. 35-54.

[31] Adeyi, A.A., Majolagbe, A.O. (2014): Assessment of groundwater quality around two major active dumpsites in Lagos, Nigeria Global Journal of Science Frontier Research: B Chemistry, 14(7), pp. 1-14.

[32] Maria, J.B., Graca, C. (2006): Identification of similar environmental areas in Tagus Estuary by using multivariate analysis. Ecological Indices, 6, pp. 508-515.

[33] Kazi, T.G., Arain, M.B., Jamali, M.K., Jalbani, N., Afridi, H.I, Sarfraz, R.A. (2009): Assessment of water quality of polluted lake using multivariate statistical techniques: A case study. Ecotoxicology and Environmental Safety, 72, pp. 301-309.

[34] Singh K.P., Malik A., Mohan, D., Sinba, S. (2004): Multivariate statistical techniques for the evaluation of spatial and temporal variations in water quality of Gomi River (India): a case study. Water Research, 38, pp. 3980-3992. 